REVISTA DE LITERATURA E CULTURA RUSSA

\title{
O eu e sua dualidade: uma releitura de $O$ duplo, de Dostoiévski
}

\section{The self and its duality: a rereading of The Double, by Dostoevsky}

Autor: Ana Maria Abrahão dos Santos Oliveira Universidade Federal Fluminense, Niterói, Rio de Janeiro, Brasil Edição: RUS Vol. 12. No 20

Publicação: Dezembro de 2021 DOI: https://doi.org/10.11606/issn.2317-4765.rus.2021.190497 


\section{O eu e sua dualidade: uma releitura de $O$ duplo, de Dostoiévski}

\section{Ana Maria Abrahão dos Santos Oliveira*}

Resumo: 0 artigo pretende elaborar uma releitura da novela $O$ duplo (1846/2013), do escritor russo Fiódor M. Dostoiévski (1821-1881), tendo como foco a temática da duplicidade como um desdobramento do eu, segundo a visão psicanalítica freudiana, além de abordar o aspecto da estrutura da obra e a questão do dialogismo, na concepção de Mikhail Bakhtin (1997).

\begin{abstract}
The article intends to draw up a rereading of the novel The double $(1846 / 2013)$, by the Russian writer Fyodor M. Dostoevsky (1821-1881), focusing on the theme of duplicity as an offshoot of the self, according to the Freudian psychoanalytic view, in addition to addressing the structure of the work and the question of Dialogism, in the conception of Mikhail Bakhtin
\end{abstract} (1997).

Palavras-chave: Dostoiévski; Desdobramento do eu; Visão psicanalítica; Dialogismo

Keywords: Dostoevsky; Unfolding of self; Psychoanalytic view; Dialogism 
* Doutora em Estudos de Literatura e Mestre em Letras pela Universidade Federal Fluminense/ CNPq. Professora de Literatura (SEEDUC - RJ) Autora de vários artigos acadêmicos e de capítulos de livros. Lattes: http://lattes. cnpq.br/4309042503504049; https://orcid.org/0000-00018306-2706; abrahaoana19@ gmail.com

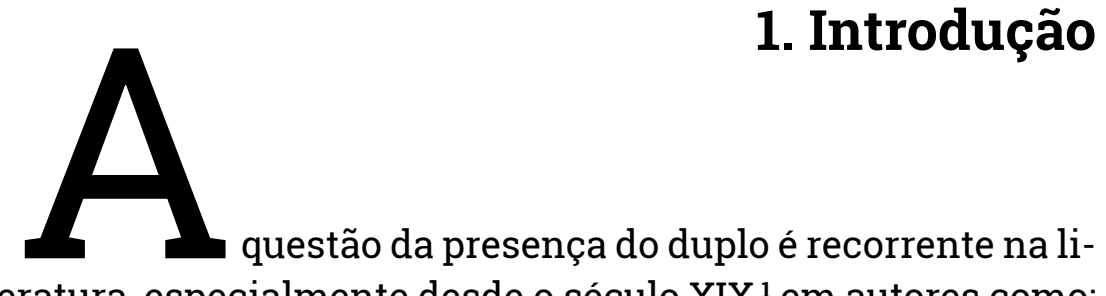
teratura, especialmente desde o século XIX, ${ }^{1}$ em autores como: Oscar Wilde, em O retrato de Dorian Gray (1890); Edgar Allan Poe, em Willian Wilson (1839); E.T.A, Hoffman, em O homem da areia (1815), e, já na contemporaneidade, com José Saramago, em $O$ homem duplicado (2002), para citarmos alguns exemplos.

A novela O duplo (2013), de Dostoiévski, também publicada há dois séculos, ${ }^{2}$ como as três primeiras obras mencionadas anteriormente, trata dessa questão do desdobramento da personalidade. Essa temática, simbolizada pela presença de duplos, ganhará profundidade tanto psicológica quanto filosófica nos romances conhecidos da maturidade e muito aclamados pela crítica ao longo do tempo, como "Crime e castigo (Raskólnikov³/Svidrigáilov), O idiota (Nastácia Filíppovna/Rogógin) [...] e Os irmãos Karamázov(Ivan/Smierdiakóv, Ivan e o diabo)" (BEZERRA, 2013, p. 237), dentre outros.

1 Segundo Rosset (2008), a temática do duplo remonta ao teatro antigo, "como no Anfitrião [206 a.C, aproximadamente] ou em Os Menecmas, de Plauto [251-184 a.C.]" (ROSSET, 2008, p. 85).

20 ano da primeira publicação de 0 duplo é 1846. Frank (2018) assinala que o escritor pretendia fazer uma revisão no texto, mas não o fez imediatamente porque foi preso em 1849. 0 escritor esteve na iminência de ser executado por seu envolvimento com um grupo em que se discutiam concepções socialistas. "Dostoiévski era membro do famoso Ciclo de Petrachévski, grupo que se reunia, semanalmente, [...] para discutir ideias dos socialistas utópicos. Por isso foi preso (1849) e condenado à morte com outros membros do ciclo" (BEZERRA, 2005, p.67-68). No momento em que a execução seria realizada, a pena foi comutada pelo cumprimento de trabalhos forçados, como se lê na carta que foi escrita a seu irmão: "Hoje, 22 de dezembro, fomos levados à praça de armas do regimento Semeónovski. Ali foi lida para todos nós a sentença de morte, deram-nos a cruz para beijar... [...] Por fim, bateu o sinal, fizeram voltar os que estavam presos aos postes, e leram para nós que sua majestade imperial nos dava a vida" (BEZERRA apud DOSTOIÉVSKI, 2002, p. 12-13). 0 escritor foi libertado em 1854.

3 A questão da duplicidade é muito recorrente na obra de Dostoiévski, conforme Frank (2003), e como exemplo cita o nome de Raskólnikov, o protagonista de Crime e castigo, que é derivado de raskol, cujo significado é cisão. Frank (2003) assinala que raskol pode ser traduzido por "cisma" (FRANK, 2003, p. 111). 
Tendo em vista essa abordagem, discorreremos no presente artigo sobre a visão psicanalítica freudiana do conceito de duplo e seus desdobramentos, além de tratarmos do aspecto da estrutura e do dialogismo presentes na novela dostoievskiana. Como embasamento teórico e crítico, fundamentamo-nos nas obras de Mikhail Bakhtin (1997), Joseph Frank (2003, 2018), Freud (2010, 2019), Jones (1990), Schnaiderman (2000), Bezerra $(2006,2013)$, dentre outros.

\section{O duplo de Dostoiévski}

O duplo, de acordo com a crítica, caracteriza-se como uma produção literária experimental de Dostoiévski, que viria a ganhar maior agudeza nas obras posteriores, como mencionamos anteriormente. A recepção da novela não foi muito positiva, ${ }^{4}$ ao contrário do que havia ocorrido com o primeiro livro publicado pelo escritor, Gente pobre, que veio a público no mesmo ano (1846). Como assinala Vássina (2013), a crítica russa não compreendeu a experimentação estética arrojada de Dostoiévski. Nesse contexto, apenas o crítico Valerian Máikov conseguiu perceber o ousado experimento do jovem escritor, destacando o estilo do autor e a importância da investigação psíquica do protagonista, conforme destaca Frank (2018):

Em O duplo, o estilo de Dostoiévski e seu amor pela análise psicológica expressam-se em toda a plenitude e originalidade. Nessa obra, ele mergulha tão fundo na alma humana, perscruta com tal destemor e paixão as maquinações secretas dos sentimentos, pensamentos e ações humanas, que a impressão deixada por $O$ duplo só é comparável à de um pesquisador que investiga a composição química da matéria (FRANK, 2018, p. 273 apud MAIKÓV, 1891, p. 325).

\footnotetext{
4 Frank (2018), ao analisar 0 duplo, inicia o capítulo assinalando que a novela pertence a uma "ficção menor de Dostoiévski" (FRANK, 2018, p. 379), entretanto, mais adiante, destaca que a obra é uma "verdadeira investigação do processo de enlouquecer", comparando o autor de Crime e castigo a Gógol: "[...] Dostoiévski acentua o aspecto humanamente trágico do retrato das frustrações psicossociais, que em Gogol é relativamente afável" (FRANK, 2018, p. 384).
} 
De acordo com essa visão, o autor russo embrenha-se pelos locais mais recônditos da alma humana, representando, assim, o caos da consciência do indivíduo. Esse mergulho intenso na psique humana estará presente em toda a sua obra posterior.

Tendo em vista essa investida de Dostoiévski na representação do psiquismo humano, Bezerra (2013) assinala que o romancista russo manifestava, já há algum tempo, interesse por enfermidades mentais. "Já se interessava por obras que estudavam 'doenças do cérebro', doenças mentais, o sistema nervoso [...] e questões de natureza psicológica", e que a novela apresenta teor autobiográfico, uma vez que o autor padecia de uma enfermidade semelhante à epilepsia, "além de ser um arguto observador de si mesmo, sobretudo do dualismo de sua personalidade" (BEZERRA, 2013, p. 237). É o próprio Dostoiévski quem revela em carta a Ekaterina Yunga, em 1880, essa peculiaridade relacionada à duplicidade de sua personalidade, de acordo como biógrafo Boris Búrsov, em A personalidade literária (1974):

[A duplicidade] é o traço mais comuns das pessoas...não inteiramente comuns. Um traço que, em linhas gerais, é inerente à natureza humana, mas que nem de longe se encontra em qualquer natureza [...] esse desdobramento que há na senhora é exatamente igual ao que há em mim e que sempre houve em toda a minha vida. Isto é um grande tormento, mas ao mesmo tempo um grande prazer (BEZERRA, 2013 apud BÚRSOV, 1974).

Reconhecendo em si mesmo a marca da duplicidade, o escritor russo admite, paradoxalmente, o quanto essa peculiaridade é causa de seu sofrimento, mas também de seu deleite. Não por acaso, Dostoiévski construiu muitos personagens, alguns dos mais impetuosos e intensos da literatura universal, em que essa característica se manifesta.

Em $O$ duplo, obra de sua juventude, o escritor russo cria uma narrativa em que é relatada a história das agruras e desventuras por que passa o conselheiro titular Yákov Pietróvitch Golyádkin, ${ }^{5}$ que trabalha numa repartição e que se coloca

5 Conforme Bezerra (2013), o sobrenome Golyádkin é derivado de golyadá, golyadka, cujo 
como alvo implacável de perseguição por parte de seus chefes e de seus colegas de trabalho, assumindo sempre a posição de provável vítima de suas artimanhas.

Após uma consulta com o médico Crestian Ivánovitch $\mathrm{Ru}-$ tenspitz, Golyádkin decide entrar numa festa na casa dos Beriendêivi, mesmo sem ter sido convidado, numa tentativa totalmente frustrada de se embrenhar na alta sociedade de Petersburgo, e é expulso sumariamente do evento. Humilhado, sai vagueando pelas ruas da cidade "[...]precipitou-se para fora dali, para algum lugar ao ar livre, sem rumo....". Completamente desnorteado, o conselheiro parecia não saber onde ir e como agir: "[...] estacava feito um poste no meio da calçada [...] depois arrancava num estalo como um doido e corria, corria de forma desabalada, como se fugisse da perseguição de alguém" (DOSTOIÉVSKI, 2013, p. 62; 66). Imerso na névoa e enfrentando uma temperatura baixíssima, avista um vulto, em tudo muito semelhante a ele.

De certo modo, ele agora reconhecia, reconhecia quase de todo esse homem. [...] O senhor Golyádkin conhecia perfeitamente esse homem. [...] O senhor Golyádkin reconhecera por completo o seu amigo noturno. $O$ amigo noturno não era senão ele mesmo - o próprio senhor Golyádkin, outro senhor Golyádkin, mas absolutamente igual a ele - era, em suma, aquilo que se chama o seu duplo, em todos os sentidos... (p. $70 ; 72 ; 74)^{6}$

O conselheiro certifica-se de que o outro é exatamente igual a ele e dialoga animadamente com aquele que era o seu duplo (Golyádkin segundo, como vai se referir o narrador, mais adiante). Sente-se feliz por poder usufruir de sua companhia, em sua casa, o que, de algum modo, era um alívio para o seu isolamento, além de revelar ao leitor traços de seu caráter, como a empatia com o outro (o seu duplo), que acreditava ser outra pessoa. "Golyádkin primeiro livra-se, ainda que por pou

significado é "pobre, indigente, mendigo, miserável etc" (BEZERRA, 2013, p. 53), ou seja, um desvalido, um coitado, tal como é representado o conselheiro titular na narrativa.

6 A partir desse ponto, colocaremos apenas as páginas referentes a cada citação, quando nos referirmos ao texto da obra, visto que utilizamos a edição: Dostoiévski, F. O duplo. Trad. Paulo Bezerra. São Paulo: Ed. 34, 2013. 
co tempo, de sua terrível solidão e revela sua real humanidade ao solidarizar-se com o outro, que, por ora, não tem onde morar" (BEZERRA, 2013, p. 243).

Como se sente alijado do ambiente em que vive, a ilusão de ter encontrado um amigo faz com que Golyádkin recupere o ânimo, rompa um pouco seu isolamento e viva alguns momentos de companheirismo ao lado de seu duplo. Entretanto, no decorrer da narrativa, Golyadkin primeiro e Golyádkin segundo entrarão numa terrível disputa, como imagina o primeiro. Na visão fantasiosa do conselheiro, o seu duplo tudo fará para depreciar, para desprestigiar a sua figura na repartição onde trabalhava, pois Golyádkin segundo tomará o lugar de Golyádkin primeiro. Essa "mudança" levará o conselheiro a tomar atitudes descabidas e desconexas. Desconfiado, como sempre, ao encontrar seu duplo na repartição, não compreende como os colegas de trabalho não estranham a presença do seu igual. Por essa razão, tomado de grande surpresa, sua atitude foi "lançar um rápido olhar ao redor para ver [...] se aquilo não estaria provocando algum gracejo na repartição [...] Contudo, para maior surpresa do senhor Golyádkin, não se viu nada semelhante[...]" (p. 81). O conselheiro não conseguia aceitar o fato de seus colegas de trabalho não ficarem perplexos ao se depararem com alguém semelhante a ele em todos os aspectos.

Parecia um comportamento fora do bom senso. [...] a coisa era estranha, hedionda, absurda [...] Aquele que agora estava sentado frente a frente com o senhor Golyádkin era - horror para o senhor Golyádkin -, era - vergonha para o senhor Golyádkin -, era o pesadelo da véspera do senhor Golyádkin; em suma, era o próprio senhor Golyádkin que agora estava sentado ali à mesa, boquiaberto e com a pena imóvel na mão; não era aquele que trabalhava como auxiliar de seu chefe na seção [...] não, era outro senhor Golyádkin, totalmente outro, mas ao mesmo tempo idêntico ao primeiro [...] de tal forma que se os pegassem e os colocassem lado a lado, ninguém, decididamente ninguém se atreveria a definir quem era mesmo o Golyádkin de verdade e quem era o novo, quem era o original e quem era a cópia (p. 82). 
O conselheiro desacreditava do que estava vendo, uma vez que não poderia crer que houvesse alguém absolutamente idêntico a ele na repartição, e que, não obstante, essa aparição não causasse a mínima estranheza aos demais funcionários. "Será que estou dormindo, tendo visões?" (p. 83-84).

Nesse contexto, Dostoiévski, por sua vez, utiliza o artifício de construir um ambiente que leva o leitor à constante dúvida com relação à existência ou não do duplo, pois este, algumas vezes, dialoga com os colegas e com a chefia, parecendo, portanto, ser alguém real. "Depois de dizer de passagem umas duas palavras necessárias a Andriêi Filíppovitch, trocar umas palavras com mais alguém, desfazer-se em amabilidades com outros[...]" (p. 119). Dessa forma, o conselheiro vê-se numa situação em que é confrontado com suas próprias imperfeições, ${ }^{7}$ suas angústias, suas limitações. Como assinala Jones (1990), Dostoiévski utiliza uma estratégia em que se concretiza uma transferência do "discurso de uma boca para outra, obrigando seu herói a reconhecer-se em outra pessoa, porém com a entonação de paródia ou ridículo"8 (JONES, 1990, p. 38).

Mesmo sem aceitar completamente que estava sendo substituído integralmente por seu duplo, Golyádkin estava tomado por grande angústia e temor e empenhava-se para tentar, em vão, desmascarar seu duplo a todo custo. "Saberia como agir depois, como a dispor todo o seu plano de ação para fazer baixar a crista à arrogância e esmagar a serpente que morde o pó desdenhando da impotência" (p. 122). Assim se sucedem algumas investidas frustradas e desesperadas do senhor Golyádkin, que representa um papel cada vez mais ridículo perante

\footnotetext{
7 Consoante Schnaiderman (2000), o personagem, nas narrativas do autor é, muitas vezes, o "'anti-herói dostoievskiano' [...] representa o clímax do 'desligamento do solo', em que vivia boa parte da sociedade russa, mas também é crítico feroz desta" (SCHNAIDERMAN, 2000, p. 8). Grifo do autor. É nesse sentido que Golyádkin é um antecessor, de alguma maneira, do protagonista de Memórias do subsolo (2000), que também, mas em maior intensidade, é um homem angustiado que se confronta o tempo todo em relação ao seu papel numa sociedade que o despreza, que faz com se sinta alijado. Em 0 duplo, temos o discurso de Golyádkin: "Sou um homem pequeno, o senhor mesmo sabe [...]" Nas Memórias do subsolo: "Sou um homem doente... Um homem mau. Um homem desagradável. Creio que sofro do fígado" (DOSTOIÉVSKI, 2000, p. 65).

8 "[...] discourse from one mouth to another forcing his hero to recognize himself in another person, though with the intonation of parody or ridicule." Tradução nossa.
} 
os funcionários da repartição e a chefia. Nesse contexto, cenas cada vez mais humilhantes ocorrem: "[o senhor Golyádkin segundo] lançou um olhar irônico para o senhor Golyádkin primeiro, [...] com a petulância que lhe era própria[...] ao lado dos funcionários, disse uma palavrinha a um, cochichou com outro [...]". Sentindo-se totalmente enjeitado e aniquilado, o conselheiro sucumbe à mais profunda tristeza: "Desesperado e abandonado por todos[...] com uma expressão desolada no rosto, encolhido[...] Parecia que tudo estava morto para o senhor Golyádkin (p. 124).

A culminância dessa trajetória do conselheiro é o ápice da loucura. De acordo com Rosset (2008), "Nada mais frágil do que a faculdade humana de admitir a realidade, de aceitar sem reservas a imperiosa prerrogativa do real" (ROSSET, 2008, p. 13), ou seja, a origem do tema do duplo é, irremediavelmente, a recusa do real. O conselheiro Golyádkin se recusa a ver seu lado vil e desonesto. Por essa razão, cria um "duplo" de si mesmo, a quem pode julgar e apontar os defeitos. Nessa perspectiva, ainda desejando "enfrentar" o seu duplo, ao retornar à residência de Olsufi Ivánovitch, de onde fora expulso anteriormente por não ter sido convidado, é recebido com certa estranheza pelos presentes, "todos o olhavam com uma curiosidade estranha, com uma simpatia inexplicável, enigmática" (p. 227). O anfitrião mostrou-se gentil com Golyádkin, por ter conhecimento, com certeza, do fim que levaria o conselheiro. "Olsufi Ivánovitch aparentemente recebeu muito bem o senhor Golyádkin [...] com ar de tristeza solene, mas ao mesmo tempo benévola" (p. 226). A gentileza de Ivánovitch justificava-se pela iminente chegada do médico Crestian Ivánovitch, que conduziria Golyádkin a um hospital psiquiátrico. Até mesmo nesse momento derradeiro da narrativa, o conselheiro visualiza aquele que, em sua imaginação, quer destruí-lo impiedosamente: seu duplo. "[...] o duplo, conforme seus hábitos torpes, o empurrava pelas costas. O infeliz senhor Golyádkin primeiro lançou seu último olhar a tudo e a todos e, tremendo como um gatinho [...]". Já dentro da carruagem que o conduzia, começou a se sentir mal: "[...] no peito uma dor abafada; o sangue borbotava quente em sua cabeça; ele sentia falta de ar, queria desabotoar o capote, denudar o peito[...] Por fim desfaleceu..." (p. 232). 
Ao acordar do desmaio, em meio à silenciosa escuridão da estrada desconhecida, o desespero do conselheiro Golyádkin chegou ao limite do insuportável e às raias da insanidade extrema, pois viu não o médico, mas sim o seu duplo: "Não é Crestian Ivánovitch!... Quem é? Ou é ele? É ele! É Crestian Ivánovitch, só que não o antigo, mas outro Crestian Ivánovitch! É um Crestian Ivánovitch terrível!..." (p. 234); além de ouvir o discurso cruel e pedante do médico: "O senhor vai receber do Estado casa com aquecimento, Licht ${ }^{9}$ e uma criada, o que não merece - rosnou Crestian Ivánovitch de modo severo e terrível, como se pronunciasse uma sentença" (p. 234).

O fim trágico do solitário conselheiro Golyádkin se concretiza quando é obrigado a deixar, peremptoriamente, o mundo dos denominados homens "normais" e embrenhar-se no universo do desdobramento total do indivíduo, o hospital para pessoas acometidas de enfermidades das faculdades mentais.

\section{O desdobramento do eu e a interpretação psicanalítica em $O$ duplo}

Na narrativa de $O$ duplo surge um embate entre Golyádkin e o seu duplo (Golyádkin segundo), situação que aponta o comportamento de caráter dúbio, emergindo dessa conduta, uma contenda sem fim entre o conselheiro e seu sósia.

Tendo em vista esse contexto, Máikov, crítico literário russo já mencionado acima, destaca como o escritor demonstra interesse pelo exame psíquico dos indivíduos, com o intuito de perscrutar a alma humana, uma vez que a visão do próprio Dostoiévski também se encaminhava nessa direção, como assinala Grossman (1967), referindo-se à declaração do autor acerca de $O$ duplo: "Nunca realizei em literatura algo mais sério que esta ideia" (GROSSMAN, 1967, p. 141 apud DOSTOIÉVSKI), afirmação que vem ao encontro da asserção de Bezerra (2013): "O duplo é o laboratório de todos os grandes romances dostoievskianos" (BEZERRA, 2013, p. 237)".

9 Conforme nota do tradutor: "'Luz', em alemão no original" (BEZERRA, 2013, p.234). 
Ao abordar sobre a questão da duplicidade do eu, Freud (1900/2019), no ensaio $O$ infamiliar, ${ }^{10}$ discorre sobre uma patologia em que se manifesta o reconhecimento do eu em outrem:

Trata-se do âmbito do duplo, ou seja, [...] a identificação com outra pessoa, de modo que esta perde o domínio de seu $\mathrm{Eu}$ ou transporta o Eu alheio para o lugar do seu próprio, ou seja, duplicação do Eu, divisão do Eu, confusão do Eu [...] a repetição dos mesmos traços fisionômicos, o mesmo caráter, o mesmo destino [...] O fato de que exista tal instância, que pode tratar o restante do Eu como objeto, ou seja, que as pessoas sejam capazes de auto-observação (FREUD, 2019, p. 69).

Na visão freudiana, num quadro doentio do delírio no indivíduo, manifesta-se um isolamento da consciência, sendo esta apartada do eu, fazendo com que haja a destruição da unidade da identidade, isto é, o sujeito é direcionado para o seu limite, ao se reconhecer "estranho a si próprio" (ROCHA; IANNINI, 2019, p. 185).

Como assinala Chaves (2019) acerca da questão da ocorrência do duplo na literatura, os autores do século XIX, tais como Hoffmann e Poe, proporcionaram um afastamento dos padrões estéticos do Renascimento, na interpretação de Freud. Mas o autor de Os irmãos Karamázov operou uma mudança no sentido, diferenciada daquela dos escritores mencionados, uma vez que, em sua obra, "os demônios não estão mais fora de nós, não chegam a nós vindos de fora, mas, ao contrário, habitam-nos" (CHAVES, 2019, p. 156).

Nesse sentido, na obra de Dostoiévski, os demônios travam um embate com o próprio eu, visto que irrompem dentro do indivíduo e com ele convivem, de modo traiçoeiro, muitas vezes, sem que o sujeito se aperceba.

Tendo em vista essa discussão, com o protagonista de $O d u$ plo ocorre um desdobramento do eu num momento em que o personagem está extremamente abalado emocionalmente e com baixa autoestima:

100 ensaio Das Unheimliche já foi traduzido para o português, no Brasil, como: "0 estranho", Imago, 1996; "O inquietante", Companhia das Letras (2010), "O infamiliar", Autêntica (2019), sendo a última utilizada na escrita desse artigo. 
Diremos mais: nesse momento, o senhor Golyádkin não só queria fugir de si mesmo, mais deixar-se destruir completamente, não ser, virar pó. [...] ao mesmo tempo, ele teve a impressão de que alguém estava ali na mesma ocasião, no mesmo instante, em pé ao seu lado, ombro a ombro com ele, também apoiado na balastrada do cais, e - coisa estranha! [...] Mas o que é isso? - pensou aborrecido -, o que está se passando comigo, será que enlouqueci de fato? (p. 66,67, 69).

Nesse contexto, a fronteira entre realidade e fantasia são diluídas. $O$ indivíduo é conduzido ao limite, vê a si mesmo como um estranho. Esse processo ocorre com o intuito de o sujeito criar para si um mecanismo de defesa:

[Há um] propósito de defesa que projetou [o duplo] para fora do $\mathrm{Eu}$, como se fosse um estranho. [...] O duplo era uma garantia contra o declínio do Eu, [...] poder da morte. A criação de uma duplicidade dessa ordem como defesa contra a destruição tem seu contraponto em uma representação da linguagem onírica, na qual a castração"11 ama expressar-se por meio da duplicação ou da multiplicação ou da duplicação do símbolo genital. [...] O duplo se tornou uma imagem do horror" (FREUD, 2019, p. 69;73).

Esse quadro de amargura e repulsa dominam os pensamentos de Golyádkin, ao enxergar, simultaneamente, uma cópia de si mesmo e um estranho ou infamiliar. Conforme a concepção freudiana, o duplo vincula-se à dor da castração, aqui simbolizada pela limitação imposta pelo meio onde vivia, o que faz com que se projete em seu duplo, a fim de concretizar os seus desejos mais íntimos.

Ao encontrar o seu duplo, pela primeira vez, em Golyádkin, emerge uma visão em que a realidade se apresenta de forma desdobrada, verdadeiramente, como se o conselheiro estives-

110 complexo de castração, segundo a concepção freudiana, é "o sentimento inconsciente de ameaça experimentado pela criança quando ela constata a diferença anatômica entre os sexos[...] compõe-se de duas representações psíquicas. Por um lado, o reconhecimento, que implica a superação da renegação, inicialmente observada, da diferença anatômica entre os sexos. Por outro, como consequência dessa constatação, a rememoração ou atualização da ameaça de castração, no caso do menino, ameaça esta que é ouvida ou fantasiada" (ROUDINESCO; PLON, 1998, p. 105-106). 0 complexo da castração representa a interdição, o limite entre o permitido e o proibido. No caso de Golyádkin, este limite foi ultrapassado quando o personagem concebeu o seu duplo (Golyádkin segundo), que poderia tomar todas as atitudes que ele mesmo não conseguia porque não possuía coragem suficiente para realizar o que realmente desejava. 
se vivendo duas vezes, pois tudo o que lhe ocorre acontece duplamente aos seus olhos. Nesse sentido, diante da situação com que se depara, os fatos lhe causam evidente estranhamento. $O$ conselheiro se desdobra, tanto mental quanto materialmente, assistindo a esse processo tomado de profunda angústia, embora tente, no decorrer da narrativa, travar um embate contra a existência de Golyádkin segundo, seu duplo. "No Eu se forma, lentamente, uma instância singular, que se pode, além disso, contrapor ao restante do Eu e que serve à auto-observação e à autocrítica, conduzindo o trabalho de censura psíquica" (FREUD, 2019, p. 71). Portanto, no processo em que se apresenta um eu fragmentado, o duplo que dessa cisão resulta é alvo de observação, de crítica por parte daquele do qual se desdobrou. Ou seja, o duplo causa estranhamento ao eu, colocando-o numa posição em que se configura uma atmosfera angustiante, conflituosa e surpreendente. "Podemos enveredar por uma travessa - disse em tom tímido o humilde companheiro de viagem[...] Já o senhor Golyádkin não entendia absolutamente o que se passava consigo. Ainda não se recobrara da estupefação" (p. 94). Há, dessa forma, uma profunda sensação de "desamparo e infamiliaridade" (FREUD, 2019, p. 75). Ora, nada mais ameaçador para o eu do conselheiro do que se enxergar fragmentado e degradado no seio da realidade em que está inserido. Conforme Rocha e Iannini (2019), quando o narcisismo ${ }^{12}$ humano está fragilizado, esse enfraquecimento se mostra de forma dúbia: "O golpe ao narcisismo humano é um golpe que, na verdade, se desdobra em dois: um que tem por alvo a explicitação da finitude [...] e outro que [...] confronta o sujeito com o desamparo" (ROCHA; IANNINI, 2019, p. 190). Dessa forma, o eu enfrenta a possibilidade da falta de proteção, da fragilidade e da provável iminência da morte.

Golyádkin, diante do anseio que sempre nutriu de fazer parte da alta roda da sociedade, e dos obstáculos que enfren-

12 Como assinala Freud (2010): "0 termo 'narcisismo' vem da descrição clínica e foi escolhido por P. Näcke, em 1899, para designar a conduta em que o indivíduo trata o próprio corpo como se este fosse o de um objeto sexual, isto é, olha-o, toca nele e o acaricia com prazer sexual, até atingir plena satisfação mediante esses atos" (FREUD, 2010, p. 10). Nessa perspectiva, pode-se dizer que, no caso do duplo, há uma reprodução da imagem do próprio eu, que enxerga a sua cópia como alguém real, como no caso do conselheiro Golyádkin. 
taria para realizar o que almejava, sente-se perdido e incompreendido, uma vez que se defronta com a evidente postura dissimulada que imperava na sociedade russa, cujos preceitos vigentes iam de encontro aos princípios do conselheiro. A alta sociedade russa da época apresentava-se corrompida e degradada e a ambição do conselheiro sobrepõe-se a sua baixa autoestima. Entretanto, com o surgimento do duplo, o conselheiro se transforma, visto que Golyádkin age para que, de todas as maneiras, possa ser distinguido daquele que é o seu igual e que se apresenta como seu maior rival. "O fato é que o senhor Golyádkin primeiro, em sã consciência, por vontade própria e diante de testemunhas, apertou solenemente a mão daquele a quem chamava seu inimigo mortal [o seu duplo]" (p. 171). Golyádkin, ao se sentir muito acuado pelas "armadilhas" de seu duplo, sucumbe. "Talvez, se alguém quisesse, se alguém quisesse mesmo, [...] se quisesse transformar o senhor Golyádkin num trapo velho, [...] transformaria sem resistência e impunemente" (p. 123). Nesse contexto de sofrimento e desolação, o conselheiro estava totalmente rebaixado pela humilhação e pela desmoralização, perante os colegas e chefes, na repartição onde trabalhava, de modo, aparentemente irreversível. "Ninguém lhe deu a mão. Uns deram apenas um 'boa noite' e se afastaram; [...] houve simplesmente quem lhe desse as costas, mostrando que o haviam ignorado por completo [...] (p. 170).

Nessa trajetória sem possibilidade real de retorno, Golyádkin primeiro assume uma postura de aceitação, de resignação e de rebaixamento que lhe é imposto por seu duplo, inexoravelmente.

Na novela $O$ duplo, são relevantes também as abordagens relativas à estrutura e ao dialogismo, sendo o último um conceito fundamental na obra de Mikhail Bakhtin, no qual nos deteremos na seção seguinte. 


\section{A estrutura da obra e 0 dialogismo em $O$ duplo}

Conforme Bezerra (2013), há em $O$ duplo uma divisão em duas partes distintas: na inicial, deparamo-nos com o protagonista Golyádkin já apresentando pensamentos fantasiosos, quando se dirige à casa de Olsufi Ivánovitch, "Sentia-se muito mal, com a cabeça na mais completa desordem e caos" ( $p$. 43), de onde será expulso, uma vez que não fora convidado, saindo de forma errante e desnorteada e, pela primeira vez, encontrando o seu duplo. No segundo momento, já próximo ao fim da narrativa, Golyádkin está novamente na casa de Olsufi Ivánovitch, porém, do lado de fora, ocultado por uma pilha de lenha, no pátio da residência, certo de que levará a filha de Ivánovitch, Clara. É encontrado e levado para dentro da casa, gentilmente, e, lá chegando, o conselheiro encontra seus colegas da repartição, pessoas da alta sociedade e, como não poderia deixar de ser, o seu duplo, que se encontra totalmente entrosado com os burocratas da cidade. Estranha o fato de ser tratado com muita delicadeza. Entretanto, quando pensa que, finalmente, conseguirá se inserir na sociedade de São Petersburgo, surge no salão o médico Crestian Ivánovitch, que o levará para o manicômio. "No primeiro caso, a visita ao seu médico serviu como entrada no motivo central da narrativa; no último, como saída do mundo dos homens [...]" (BEZERRA, 2013, p. 245).

Dentro dessa perspectiva e destacando a questão do dialogismo na obra, Bakhtin (1997) assinala que "toda a vida interior de Golyádkin se desenvolve dialogicamente" (BAKHTIN, 1997, p. 213), enumerando alguns exemplos que ratificam sua teoria, quando o conselheiro inicia um diálogo consigo mesmo, no momento em que vai procurar o médico Crestian Ivánovitch: "Pensando bem, será que tudo isso está certo? [...] descendo da carruagem à entrada de um prédio de cinco andares na rua Litiêinaia [...] -, será que tudo isso está certo? [...] Será oportuno? [...] continuou ele subindo a escada[...]" (p. 17). O segundo exemplo, segundo o filósofo russo, possui maior complexidade e agudeza, uma vez que o duplo do conselheiro já havia surgido: 
[...] porque, de vez em quando seu coração ficava tão atormentado que ele não sabia com que se consolar. "De resto, esperemos um dia e a alegria virá. Por que, pensando bem, o que vem a ser isso? [...] Vamos meu jovem amigo, tratemos de raciocinar [...] Vê, um homem igualzinho a ti, em primeiro lugar, igualzinho a ti, em primeiro lugar, igualzinho a ti. Sim, mas o que há de especial nisso? Só porque existe um homem assim terei que chorar? O que é que eu tenho a ver com isso? [...] Ora, é estranho e prodigioso, como andam dizendo, que irmãos siameses... Arre, por que siameses? Suponhamos que sejam gêmeos, mas acontece que por vezes grandes homens pareceram esquisitões. Até se sabe pela história que o famoso Suvórov cantava como um galo... Ah, sim, mas tudo isso fazia parte da política [...] Não sou um intrigante e disto me orgulho. Sou puro, franco, asseado, agradável, complacente... (p. 93).

Em O duplo, prevalece o diálogo de Golyádkin consigo mesmo, que se concretiza num autoquestionamento constante, sobretudo após o aparecimento daquele que vê como sua cópia integral. Esse diálogo interior se impõe diante da obrigatoriedade de ter de conviver com seu duplo. A presença do seu "igual" o incomoda a ponto de ter de se justificar perante si mesmo, afirmando que o que está acontecendo consigo não passa de uma esquisitice. Afinal, pessoas famosas na Rússia, como o general Suróvov, conhecido como aquele militar que afirmava "nunca ter perdido uma batalha" (BEZERRA, 2013, p. 93) também possuía suas bizarrices. Sendo assim, indagava-se por que com ele seria diferente.

Tendo em vista os constantes diálogos interiores de Golyádkin, conforme a concepção bakhtiniana, em O duplo não existe o discurso monológico, pois este não se mostra suficiente para a construção do personagem. Desse modo, em cada palavra pronunciada pelo conselheiro Golyádkin existe um conjunto de vozes, apesar de que, nessa novela dostoievskiana, ainda não "haja o autêntico diálogo de consciências imiscíveis que aparecerá posteriormente nos romances. Aqui já existe um embrião do contraponto: este se esboça na própria estrutura do discurso" (BAKHTIN, 1997, p. 222). Dessa forma, a polifonia ou o diálogo de diferentes vozes, traço marcante das narrativas posteriores do autor, conforme a teoria bakhtiniana, ainda 
não está presente na narrativa de $O$ duplo, mas, sim, o diálogo interior. Golyádkin, diante das pressões que sofre e que fazem com que se sinta solitário e infeliz, tem de encarar o despertar de sua consciência delirante, o diálogo interior que desemboca na criação de outra versão de si mesmo e que poderia dar vazão a toda a sua frustração.

Além do constante diálogo interior, destaca-se também o diálogo do narrador com o leitor, que é recorrente na narrativa: "Ah, se eu fosse poeta! [...] Homero ou Púchkin; com menos talento não dá para se meter. Sem falta eu retrataria em cores vivas e largas pinceladas todo esse dia sublime, para vós, leitores. [...]" E aludindo ao comportamento do conselheiro Golyádkin, quando estava escondido, tentando entrar na festa de Clara Olsúfievna: "Ele, senhores, também está aqui [...] ele, senhores, vai indo [...] Ele, senhores, está num cantinho, esquecido num cantinho [...] ora, senhores, ele também pode entrar" (p. 49-51). Em dado momento, de modo contraditório, após se comparar com Homero e Púchkin, o narrador, com teor metalinguístico e também irônico, justifica a suposta fragilidade de sua escrita:

Já é até dispensável dizer que minha pena é fraca, chocha e obtusa para representar à altura o baile improvisado pela amabilidade incomum do grisalho anfitrião. E, ademais, como, pergunto, como posso eu, um modesto narrador das aventuras do senhor Golyádkin, a seu modo muito curiosas - como posso representar essa mistura inusitada e digna de beleza, brilho, decoro [...]todos esses jogos e risos de todas as senhoras de burocratas, [...] seus travessos pezinhos ligeiros, homeopáticos, para usar estilo elevado? (p. 45).

Ao questionar a sua própria capacidade de redigir a história, afirmando que não seria dotado de aptidão para descrever a festa de Clara Olsúfievna, uma vez que poderia apenas registrar as aventuras do conselheiro, é colocado em xeque o fazer literário e suas peculiaridades. Nesse sentido, o diálogo do narrador com seus leitores é parte integrante da experimentação estética realizada por Dostoiévski na obra, conforme foi mencionado acima. 
Bezerra (2006), ao discorrer sobre o dialogismo, assinala que, conforme Bakhtin, o "processo dialógico é uma luta entre consciências, entre indivíduos, na qual a palavra do outro abre uma fissura na consciência do ouvinte, penetra nela, entra em interação com ela e deixa aí sua marca indelével" (BEZERRA, 2006, p. 42).

Na obra $O$ duplo, a voz do narrador se une à do seu duplo, "que lhe grita aos ouvidos as suas próprias palavras e ideias". (BAKHTIN, 1997, p. 222). Essa voz arrogante e escarnecedora de Golyádkin segundo é ouvida incessantemente pelo conselheiro Golyádkin, sintoma que se agravará no decorrer da narrativa e que o levará a um caminho sem retorno.

\section{Considerações finais}

Na novela $O$ duplo, escrita por Dostoiévski ainda na juventude, a composição do personagem Golyádkin caracteriza-se, especialmente, pela cisão da personalidade do protagonista, aspecto que marcará os grandes romances dostoievskianos posteriores, tais como Crime e castigo, O idiota e Os irmãos Karamázov. Nessa perspectiva, a novela configura-se como precursora, nesse viés psicológico, com o qual o autor construirá seus personagens das obras que a sucederiam. Em Dostoiévski, os personagens são figuras angustiadas, "procurando a si mesmas, procurando construir teorias [...] para Dostoiévski, o ser humano é doente" (PONDÉ, 2003, p. 127).

A doença do conselheiro Golyádkin manifesta-se devido a sua solidão, por não conseguir se expressar, diante da opressão e da hipocrisia da sociedade russa de seu tempo, o que o leva a conceber, através de um ímpeto delirante, um duplo de si, com o fito de extravasar todo o seu descontentamento e a sua revolta, uma vez que se achava esmagado pelo peso que impunha a sua condição de funcionário subalterno, sem o reconhecimento dos pares e sem a menor possiblidade de ascensão social. 
Em meio a esse ambiente hostil e sem a menor perspectiva de evolução, aflora nesse indivíduo a duplicação do $\mathrm{Eu}$, em que, conforme a teoria freudiana, cria-se assim um intenso diálogo interior. Nesse embate, apresenta-se como vitorioso o duplo, e não aquele de quem este se originou, tanto no aspecto pessoal quanto no profissional. Com o surgimento de Golyádkin segundo, o conselheiro depara-se com a possibilidade de confrontar-se, de olhar para dentro de si e criar uma estratégia para vencer a sua inexorável condição de homem solitário e fracassado, o que o transformará num ser extremamente atormentado e delirante, que enveredará, inevitavelmente, pelos tortuosos caminhos da demência.

Tendo em vista essa narrativa pioneira, na obra de Dostoiévski sobressai a visão estética do autor russo que foi levada para as esferas mais profundas do indivíduo (OLIVEIRA, 2019), não para o inconsciente, mas para as camadas mais viscerais da consciência, promovendo, desse modo, uma notável transformação na questão da representação do ser humano na literatura.

\section{Referências bibliográficas}

BAKHTIN, M. Problemas da poética de Dostoiévski. Trad. Paulo Bezerra. $2^{\text {a }}$ ed. Rio de Janeiro, 1997.

BEZERRA, Paulo. Dostoiévski: Bobók. Tradução e análise do conto. São Paulo: Ed. 34, 2005.

BEZERRA, P. "Dialogismo e polifonia em Esaú e Jacó". In: FARACO, C. A.; TEZZA, C. \& Gilberto CASTRO, G. de. (Orgs.). Vinte ensaios sobre Mikhail Bakhtin. Petrópolis: Ed. Vozes, 2006.

BEZERRA, Paulo. "O laboratório do gênio". In: DOSTOIÉVSKI, Fiódor. $O$ duplo. $2^{\mathrm{a}}$ ed. $3^{\mathrm{a}}$ reimpressão. Trad. Paulo Bezerra. São Paulo: Ed. 34, 2013.

BEZERRA, Paulo. "Prefácio do tradutor". In: DOSTOIÉVSKI, Fiódor. O idiota. Trad. Paulo Bezerra. Desenhos: Oswaldo Goeldi. $1^{\text {a }}$ ed. São Paulo: Ed. 34, 2002. 
CHAVES, Ernani. "Perder-se em algo que parece plano". In: FREUD, S. O infamiliar e outros escritos. Seguido de O homem da areia. E.T.A. Hoffmann. Trad. Ernani Chaves, Pedro Heliodoro Tavares [O homem da areia. Trad. Romero Freitas] $1^{\text {a }}$ ed., $1^{\text {a }}$ reimp. Belo Horizonte: Autêntica, 2019.

DOSTOIÉVSKI, F. M. Memórias do subsolo. Trad. Prefácio e notas: Boris Schnaiderman. 3a ed. São Paulo: Ed. 34, 2000.

DOSTOIÉVSKI, F. M. O duplo. $2^{\text {a }}$ ed. $3^{\text {a }}$ reimpressão. Trad. Paulo Bezerra. São Paulo: Ed. 34, 2013.

FRANK, Joseph. Dostoiévski. As sementes da revolta. 1821 a 1849. Trad. Vera Pereira. $2^{\mathrm{a}}$ ed., $1^{\mathrm{a}}$ reimpr. São Paulo: Editora da Universidade de São Paulo, 2018.

FRANK, Joseph. Dostoiévski. Os anos milagrosos. 1865 a 1871. Trad. Geraldo Gerson de Souza. São Paulo: Editora da Universidade de São Paulo, 2003.

FREUD, S. Introdução ao narcisismo, ensaios de metapsicologia e outros textos. (1914-1916). Trad. Paulo César de Souza. Obras completas volume 12. São Paulo: Companhia das Letras, 2010.

FREUD, S. O infamiliar e outros escritos. Seguido de O homem da areia. E.T.A. Hoffmann. Trad. Ernani Chaves, Pedro Heliodoro Tavares [O homem da areia. Trad. Romero Freitas] $1^{\text {a }}$ ed. $1^{\text {a }}$ reimp. Belo Horizonte: Autêntica, 2019.

GROSSMAN, L. Dostoiévski artista. Trad. Boris Schnaiderman. Rio de Janeiro: Civilização Brasileira, 1967.

JONES, M. Dostoyevsky after Bakhtin: readings in Dostoyevsky's fantastic realism. Cambridge University Press, 1990.

OLIVEIRA, Ana Maria Abrahão S. "Polifonia, filosofia e misticismo em Crime e castigo, de Dostoiévski". In: FRANCELINO, Pedro Farias; SANTANA, Wilder K. Fernandes. (orgs.) Bakhtin e o círculo em fronteiras do discurso. Vol. 01. São Carlos: Pedro \& João Editores, 2019.

PONDÉ, Luiz Felipe. Crítica e profecia: a filosofia da religião em Dostoiévski. São Paulo: Ed. 34, 2003.

ROCHA, Guilherme Massara; IANNINI, Gilson. "O infamiliar, mais além do sublime" In: FREUD, S. $O$ infamiliar e outros es- 
critos. Seguido de O homem da areia. E.T.A. Hoffmann. Trad. Ernani Chaves, Pedro Heliodoro Tavares [O homem da areia. Trad. Romero Freitas] $1^{\text {a }}$ ed. $1^{\text {a }}$ reimp. Belo Horizonte: Autêntica, 2019.

ROSSET, Clement. O real e seu duplo. Ensaio sobre a ilusão. $2^{\mathrm{a}}$ ed. Trad. José Thomaz Brum. Rio de Janeiro: José Olympio Editora, 2008.

ROUDINESCO, E.; PLON, M. Dicionário de psicanálise. Trad. Vera Ribeiro e Lucy Magalhães. Supervisão da edição brasileira: Marco Antonio Coutinho Jorge. Rio de Janeiro: Zahar, 1998. SCHNAIDERMAN, Boris. Prefácio do tradutor. In: DOSTOIÉVSKI, F. Memórias do subsolo. Trad. Prefácio e notas: Boris Schaiderman. $3^{\mathrm{a}}$ ed. São Paulo: Ed. 34, 2000.

VÁSSINA, Elena. Contracapa. In: DOSTOIÉVSKI, FIÓDOR. O duplo. $2^{\mathrm{a}}$ ed., $3^{\mathrm{a}}$ reimpressão. Trad. Paulo Bezerra. São Paulo: Ed. 34, 2013.

Recebido em: 09/09/2021

Aceito em: 09/11/2021 